\title{
Reproduction of Varroa jacobsoni (Acari : Mesostigmata: Varroidae) in temperate climates of Argentina
}

\author{
JA Marcangeli, MJ Eguaras, NA Fernandez \\ Universidad Nacional de Mar del Plata, Laboratorio de Artrópodos, Fac Cs Ex y Nat, \\ CONICET, Funes 3350 (7600), Mar del Plata, Argentina
}

(Received 17 January 1990; accepted 30 October 1991)

\begin{abstract}
Summary - The proportion of mite females that reproduce was determined throughout 2 seasons of the year: autumn and spring in the temperate climates of Argentina. A greater reproduction of the parasite was recorded in springtime. A large proportion of non-reproductive females was observed in autumn. Such variation in reproduction levels could produce differential growth rhythms in mite populations during different seasons.
\end{abstract}

Varroa jacobsoni / Argentina / reproduction rate

\section{INTRODUCTION}

The mite Varroa jacobsoni is a parasite of Apis mellifera, and constitutes one of the greatest dangers for modern beekeeping (Griffiths and Bowman, 1981).

Varroa presents a complex system of reproduction and population dynamics which are not yet understood. Undoubtedly this process is regulated by factors typical of the parasite such as age, physiological conditions, fertility (Ifantidis, 1988), by host factors such as race of bee, postcapping period (Moritz and Hänel, 1984), physiological conditions (Ifantidis, 1984), previous hive history; and environmental factors such as climate and season of the year (Ritter and De Jong, 1984).
In this paper we report on the parasite's reproduction within honeybee worker brood cells in 2 different seasons: spring and autumn.

\section{MATERIALS AND METHODS}

The study was undertaken during autumn (March and April) and spring (September) 1989. The work was carried out on frames of 10 colonies of Apis mellifera ligustica, untreated by chemical agents, in apiaries within the province of Buenos Aires ( $37^{\circ} \mathrm{LS}$ ).

Eight hundred and ninety-nine worker brood cells were opened on the frames in autumn and 1003 in spring. The cells were grouped according to the number of parasites that had entered each (parasitic intensity; Margolis et al, 1982), 
and the reproduction percentages were obtained for each intensity.

According to the method of Ritter and De Jong (1984), only data from brood cells examined just prior to emergence were considered. We differentiated between the original adult female (more or less dark brown) and the very light brown adult female descendants. For statistical analysis contigency $\left(\chi^{2}\right)$ test was applied.

\section{RESULTS AND DISCUSSION}

The total number of cells invaded was 181 in autumn and 107 in spring; $25.41 \%$ and $13.08 \%$ of invaded cells in autumn and spring respectively contained more than one adult parasite (table I).

During the autumn months the number of mite females reproduced decreased, with an increase in parasitic intensity (fig 1). The reproduction percentage for cells with intensity "1" proved to be significantly greater than that for cells with intensity "2" $\left(\chi^{2}, P \leq 0.001\right)$. There were also cells with " 3 " and " 4 " mites. However, these were not taken into consideration due to their limited number ( $n=3$ and $n=4$ respectively).

During spring the number of mite females reproduced did not present significant differences with different parasitic intensities $\left(\chi^{2}, P \leq 0.001\right)$ (fig 1). During this season, the number of cells invaded by more than one mite was smaller than for the autumn period (table 1). This may be

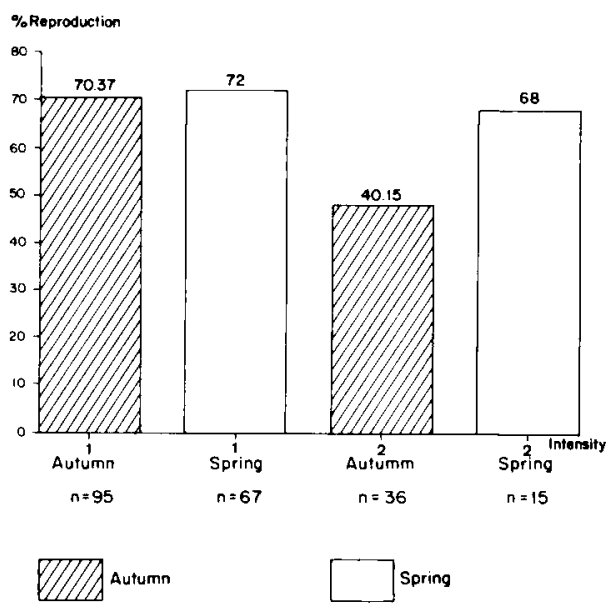

Fig 1. Relation between the number of mites reproduced in cells with different parasitic intensities.

due to the fact that in spring, the queen's greater activity reduces the probability of mites invading cells which have already been invaded.

Ritter and De Jong (1984) suggest that the microclimate and the season of the year may be some of the factors which influence the rate of mite reproduction. They found that in Europe, in temperate climates, mites thrived to reproduce in $76 \%$ of cases. In subtropical climates this percentage was reduced to approximately $50 \%$ and in South America tropical climates the percentage dropped to $43 \%$.

Table I. Number of parasitized cells: prevalence and reproduction of Varroa jacobsoni during spring and autumn.

\begin{tabular}{lllll}
\hline Season & $\begin{array}{l}\text { No of } \\
\text { parasitized } \\
\text { cells }\end{array}$ & $\begin{array}{l}\text { Prevalence } \\
(\%)\end{array}$ & $\begin{array}{l}\text { Non-reproductive } \\
\text { cells } \\
(\%)\end{array}$ & $\begin{array}{l}\text { Cells with } \\
\geq 1 \text { mite } \\
(\%)\end{array}$ \\
\hline Autumn & 181 & 20.13 & 44.19 & 25.41 \\
Spring & 107 & 10.66 & 28.03 & 13.08 \\
\hline
\end{tabular}


The results of our investigation show a differential reproduction rate during both seasons when the samples were taken. While in spring the percentage was $71.97 \%$, in autumn it was $55.81 \%$.

According to Ritter (1988) one important factor in the development of the mite is the extension of the brood area. In Argentina temperate climate areas permit brood throughout the year, although brood numbers fall in autumn and winter. Consequently $25 \%$ of invaded cells presented 2 or more mites during autumn.

Our results show minor reproductive success of mites in cells with parasitic intensities of 2 , due to the existence of a greater number of females which are nonreproductive. Conversely, in spring, when the brood area is larger, we observed a lower proportion of cells with more than 1 mite $(13 \%)$ and similar proportions of nonreproductive females in cells parasitized by 1 or more mites.

The variations in the reproduction levels of Varroa jacobsoni may account for a differential growth in the mite populations during the different seasons in temperate climates of South America. An annual follow-up of these reproductive levels of the mite is necessary to clarify the population dynamics throughout the year and the similarities and differences to the temperate climates of Europe.

\section{ACKNOWLEDGMENTS}

This investigation was supported by an International Foundation for Science Grant from Sweden, No B/1446-1 to N Fernandez. JA Marcangeli is an Initiation Grant Fellow at the Universidad Nacional de Mar del Plata, and MJ Eguaras a Doctoral Grant Fellow at CONICET.

Résumé - Reproduction de Varroa jacobsoni sous les climats tempérés d'Argentine. L'étude a été faite au printemps et à l'automne 1989 sur 10 colonies d'Apis mellifera ligustica n'ayant reçu aucun traitement chimique. Huit cent quatre vingt dix neuf et 1003 cellules de couvain d'ouvrières sur le point d'émerger ont été respectivement ouvertes à l'automne et au printemps et regroupées en fonction du nombre d'acariens femelles présents dans chacune d'elles. Les acariens ont été observés en microscopie optique et classés.

Le nombre total de cellules infestées a été de 181 à l'automne et de 107 au printemps. Le nombre d'acariens fertiles est plus élevé au printemps $(71,97 \%)$ qu'à l'automne $(55,81 \%)$. En outre, le nombre d'acariens femelles qui se reproduisent diminue de façon significative avec l'augmentation du parasitisme à l'automne ( $P=$ 0,001 ; tableau I, fig 1). On n'a pourtant pas observé de différences significatives au printemps. Les résultats montrent, qu'en Argentine, les niveaux de reproduction varient avec les saisons. Ils pourraient provoquer des taux de croissance variables pour les populations de Varroa jacobsoni.

\section{Varroa jacobsoni / Argentine / taux de reproduction}

\section{Zusammenfassung - Fortpflanzung von Varroa jacobsoni in der gemäßigten Klimazone von Argentinien. Die Untersu-} chung wurde im Herbst und Frühjahr 1989 an zehn, chemisch unbehandelten Völkern der Rasse Apis mellifera ligustica durchgeführt. Im Herbst wurden 899 Arbeiterzellen geöffnet und im Frühjahr 1003. Sie wurden entsprechend der Anzahl weiblicher Milben, die in jede Zelle eingedrungen war, in Gruppen eingeteilt. Die Milben wurden unter einem Stereomikroskop klassifiziert. Die Untersuchung erfolgte ausschließlich an Zellen mit schlüpfreifen Bienen. Die Gesamtzahl befallener Zellen betrug $181 \mathrm{im}$ Herbst und 107 im Frühjahr. Es wurde beobachtet, daß die Zahl fruchtbarer Milben 
im Frühjahr größer war $(71.97 \%)$ als im Herbst $(55.81 \%)$. Ferner wurde festgestellt, daß die Zahl weiblicher Milben mit Fortpflanzung im Herbst signifikant mit dem Befall abnahm $(P=0.001$; Tab I, Abb 1). Im Frühjahr wurden jedoch keine signifikanten Unterschiede gefunden. Diese Ergebnisse zeigen, daß es in Argentinien während der Saison unterschiedlich hohe Fortpflanzungsspiegel gibt. Sie könnten verschieden hohe Wachstumsraten der Populationen von Varroa jacobsoni verursachen.

Varroa jacobsoni / Argentinien / Fortptlanzungsrate

\section{REFERENCES}

Griffiths DA, Bowman CE (1981) World distribution of the mite Varroa jacobsoni, a parasite of honeybee. Bee World 62(4), 154-163
Ifantidis M (1984) Parameters of the population dynamics of the Varroa mite on honeybee. $J$ Apic Res 22(3), 200-206

Ifantidis M (1988) Some aspects of the process of Varroa jacobsoni mite entrance into honeybee (Apis mellifera) brood cells. Apidologie 19(4), 387-396

Margolis L, Esch G, Holmes J, Kuris A, Schad G (1982) The use of ecological terms in parasitology. J Parasito/ 68(1), 131-133

Moritz R, Hänel H (1984) Restricted development of the parasitic mite Varroa jacobsoni Oud in the Cape honeybee Apis mellifera capensis Esch. Z Angew Entomol $97 \mathrm{H} 1$, 91-95

Ritter W, De Jong D (1984) Reproduction of Varroa jacobsoni Oud in Europe, the middle east and tropical South America. $Z$ Angew Ento$\mathrm{mol} 98, \mathrm{H1}, 55-57$

Ritter W (1988) Varroa jacobsoni in Europe, the tropics, and subtropics. In: Africanized Honey Bees and Bee Mites (Needham GR, Page $R E$, Delfinado-Baker $M$, Bowman CE, eds) John Wiley, New York, 349-359 